\title{
Vestibular e Enem: um debate contemporâneo
}

\author{
Aparecida da Silva Xavier Barros*
}

\section{Resumo}

Este artigo analisa as transformações mais expressivas ocorridas nos processos de admissão aos cursos de graduação no Brasil. A fundamentação teórica foi pautada em debater sobre interesses, muitas vezes ocultos, presentes nos instrumentos de seleção. No tocante aos aspectos metodológicos, trata-se de uma pesquisa de natureza descritivo-analítica. Os resultados evidenciam que os nossos processos seletivos de acesso à universidade, guiados por uma lógica individualista e competitiva, colocam o êxito quase exclusivamente como uma responsabilidade individual e dissimulam todo um conjunto de fatores que são determinantes para a aprovação dos estudantes.

Palavras-chave: Políticas educacionais. Vestibular. Enem.

\section{Introdução}

O problema deste trabalho foi construído a partir de estudos e discussões sobre o acesso às universidades brasileiras, com foco na análise da suposta neutralidade de seus instrumentos seletivos. Partimos do pressuposto de que, apesar desse acesso ter melhorado nos últimos anos, continua sendo vedado à população de baixa renda a entrada nas graduações de maior prestígio e qualidade.

Algumas questões norteiam este trabalho: Por que o êxito no vestibular não pode ser simplesmente atribuído às diferenças de capacidades, dons e méritos individuais? Para que [e a quem] servem instrumentos de seleção como o vestibular e o Enem? Haveria um sistema justo para a admissão aos cursos superiores?

A presente pesquisa se caracteriza como descritivo-analítica. As técnicas selecionadas para coleta foram os levantamentos bibliográficos e de dados estatísticos em documentos institucionais. A discussão dos resultados deu-se por categorias (BARDIN, 1977) definidas durante o processo de análise do

*Mestre em Ciências da Educação pela Universidade Lusófona de Humanidades e Tecnologias - ULHT/Portugal. E-mail: aparecidaxbarros@hotmail.com 
material e embasadas na abordagem dos autores dos textos selecionados, e na relevância de suas considerações para este estudo.

\section{Resultados e discussões}

\subsection{Paradoxos dos julgamentos de êxito ou de fracasso escolar}

Êxito e fracasso não são conceitos "científicos". São noções utilizadas pelos agentes, alunos, pais, profissionais da escola. Desse modo, as hierarquias de excelência escolar, das mais formais às mais intuitivas, são apenas representações. Entretanto, não são quaisquer representações: elas fazem lei, passam por uma imagem legítima de desigualdades bem reais de conhecimentos ou de competências (PERRENOUD, 1999).

E como são criadas estas hierarquias de excelência? Segundo Perrenoud (2003, p. 14), a "fabricação" da excelência escolar é "um processo de avaliação socialmente situado, que passa por transações complexas e está de acordo com as formas e as normas de excelência escolar, ancoradas no currículo vigente e na visão da cultura da qual a avaliação faz parte".

Perrenoud (1999) afirma que esta avaliação funciona como um "termômetro" que, com certa margem de erro, mostra desigualdades reais de domínios dos programas exigidos. Acerca de como esses "domínios" são delimitados e sobre o que separa o êxito do fracasso, ele diz o seguinte:

Primeiramente, um ponto de ruptura introduzido em uma classificação. Essa ruptura é fixada, às vezes, em função de um numerus clausus, como é o caso em um concurso; às vezes em função de um índice considerado 'normal' de êxito ou de admissão ou, ainda em função de uma definição convencional da nota ou do grau de domínio julgados 'suficientes' (1999, p. 14).

Dito de outro modo, cada avaliação apresenta uma hierarquia pontual. Portanto, em alguns casos, a diferença entre o grau de domínio desejável e o domínio tido como insuficiente pode ser representada por apenas um décimo de ponto de diferença. Nas palavras do autor, as hierarquias de excelência representam, então, uma classificação. 
[...] aqueles que estão acima do patamar são considerados como tendo êxito: pouco importa, uma vez tomadas as decisões, que tenham sido aprovados brilhantemente ou no limite. Abaixo do patamar, encontram-se aqueles que fracassaram, quer seja 'por muito pouco' ou de modo espetacular (1999, p. 14).

Todavia, não há na organização escolar uma definição institucional, explícita e unívoca do êxito e do fracasso. A imprecisão das regras e a diversidade das práticas fazem com que um aluno não receba a mesma formação e nem seja julgado em relação às mesmas normas de excelência e aos mesmos níveis de exigência. Isso ocorre porque a escola mantém avaliações e modos de interpretar muito diversos, de modo que, quando se comparam as exigências entre turmas e entre estabelecimentos, observam-se grandes variações (PERRENOUD, 1999).

Além disso, a avaliação inscreve-se sempre em uma relação social, uma transação mais ou menos tensa entre, de um lado, o professor e, de outro, o aluno e sua família. Nesse sentido, os veredictos escolares podem ser considerados: "judiciosos ou absurdos", "laxistas ou malthusianos", "imparciais ou injustos", ressalta Perrenoud (1999). Com efeito, um aluno em situação de fracasso ocupa uma posição diferenciada daquela que é atingida pelo estudante em situação de êxito.

A escola tem o poder de declarar diferenças: quem fracassa e quem tem êxito. Observando essa questão mais de perto, as posições sociais dos indivíduos também podem contribuir com as diferenças de resultados escolares? Para Bernard Charlot (2000, p. 17), "foi como diferença que a sociologia analisou o fracasso escolar nos anos 60-70". Segundo ele, é justamente na obra de Pierre Bourdieu que esta abordagem está notadamente estruturada:

Bourdieu raciocina em termos de diferença: às diferenças de posições sociais dos pais correspondem diferenças de posições escolares dos fillhos e, mais tarde, diferenças de posições sociais entre esses filhos na idade adulta. Há a reprodução de diferenças; como se opera essa reprodução? Novamente através de diferenças de "capital cultural" e de habitus (disposições psíquicas), de maneira que os filhos ocuparão, eles próprios, posições diferentes na escola (CHARLOT, 2000, p. 20). 
Bourdieu (2007) argumenta que a cultura escolar, socialmente tomada como legítima, é basicamente a cultura das classes dominantes. Isto quer dizer que os gostos, as crenças, as posturas e os valores cobrados pela escola são os mesmos assumidos pelos grupos dominantes, embora eles sejam dissimuladamente apresentados como cultura universal. Para o sociólogo,

a escola não seria uma instância neutra que transmitiria uma forma de conhecimento intrinsecamente superior e que avaliaria os alunos a partir de critérios universalistas, mas, ao contrário, seria uma instituição a serviço da reprodução e legitimação da dominação exercida pelas classes dominantes (NOGUEIRA; NOGUEIRA, 2002, p. 28).

Os estudos de P. Bourdieu evidenciaram que os indivíduos não competiam em condições igualitárias na escola, logo, as diferenças nos resultados escolares não poderiam ser explicadas como diferenças de capacidade [dons desiguais], mas por uma maior ou menor aproximação entre a cultura escolar e a cultura familiar dos alunos. Assim, apesar de limitada, conforme veremos mais adiante, não se pode desconsiderar que esta abordagem consegue "fornecer as bases para um rompimento frontal com a ideologia do dom e a noção moralmente carregada de mérito pessoal" (NOGUEIRA; NOGUEIRA, 2002, p. 34).

A relação entre o desempenho escolar e a origem social é o elemento de sustentação da teoria de Pierre Bourdieu. Para este sociólogo (2007), cada indivíduo possui uma bagagem cultural diferenciada, que pode ser facilitadora do sucesso escolar. Essa bagagem é formada por determinados componentes objetivos [externos ao indivíduo] e, também, por componentes da própria subjetividade.

O capital econômico, traduzido em termos de bens e serviços a que ele possibilita o acesso; o capital social, tomado como o conjunto de relacionamentos sociais de prestígio mantidos pela família e o capital cultural institucionalizado, que engloba basicamente os títulos escolares, fazem parte da categoria objetiva. Já a categoria subjetiva é formada, sobretudo, pelo capital cultural na sua forma incorporada. Nesse estado, porém, o capital cultural não é transmitido instantaneamente, requer tempo e dedicação até que se torne "parte integrante da 'pessoa', um habitus" (BOURDIEU, 2007, p. 75). 
Habitus é o termo utilizado por Bourdieu para denominar as estruturas da nossa subjetividade que se constituem inicialmente por meio das nossas primeiras experiências [habitus primário] e depois, de nossa vida adulta [habitus secundário]. Ele é "a maneira como as estruturas sociais se imprimem em nossas cabeças e em nossos corpos, pela interiorização da exterioridade e pela exteriorização da interioridade", afirma Corcuff (2001 apud GIZI, 2004, p. 3).

Acrescente-se ainda que, mesmo no estado objetivado, o capital cultural carrega propriedades que só se definem na relação com sua forma incorporada, ou seja, no caso dos bens culturais, por exemplo, apesar de seu legado ser oferecido formalmente a todas as pessoas, na condição de "bens simbólicos só podem ser apreendidos e possuídos como tais [ao lado das satisfações simbólicas que acompanham tal posse] por aqueles que detêm o código que permite decifrálos" (BOURDIEU, 2003 apud GIZI, 2004, p. 4).

Nessa perspectiva, Gizi afirma que "o acesso ao que é considerado capital cultural é restrito aos que possuem o código que possibilita a sua aquisição" (p. 4). Nesse domínio, a sociologia de Pierre Bourdieu discute a distinção que a escola faz entre os alunos com capital herdado e aqueles que não o possuem. Para o sociólogo francês, essa diferenciação não se configura somente a partir do fato de o indivíduo não possuir a bagagem cultural apropriada para receber a mensagem escolar, ela é feita também embasada no pressuposto de que a cultura valorizada pela escola é aquela que deve ser tomada como critério de avaliação e hierarquização dos alunos (NOGUEIRA; NOGUEIRA, 2002).

Ao analisar a questão da herança cultural familiar, Pierre Bourdieu (2007) aponta três conjuntos de disposições e estratégias de investimento escolar que tendem a ser adotados pelas classes populares e médias e pelas elites. Em relação ao primeiro grupo - possuidor de reduzido capital econômico e cultural - o investimento é moderado. Para ele, a razão de um investimento relativamente baixo está ancorada no fato de que elas teriam percebido que a falta de alguns recursos [econômicos, sociais e, principalmente, culturais] reduziria as chances de êxito.

Esperar-se-ia dos filhos que eles estudassem apenas o suficiente para se manter (o que, normalmente, dada a inflação de títulos, já significa, de qualquer forma, alcançar uma escolarização superior à dos pais) ou se elevar ligeiramente em relação ao 
nível socioeconômico dos pais. Essas famílias tenderiam, assim, a privilegiar as carreiras escolares mais curtas, que dão acesso mais rapidamente à inserção profissional. Um investimento numa carreira mais longa só seria feito nos casos em que a criança apresentasse, precocemente, resultados escolares excepcionalmente positivos, capazes de justificar a aposta arriscada no investimento escolar (NOGUEIRA; NOGUEIRA, 2002, p. 24).

No caminho oposto às camadas populares, as camadas médias, possuidoras de um volume maior de capital cultural, geralmente, tendem a investir de modo mais consistente na escolarização dos filhos ${ }^{1}$. Essa atitude se deve, por um lado, às chances objetivas de êxito que possuem e, também, às expectativas referentes à ascensão social. "Originárias, em grande parte, das camadas populares e tendo ascendido às classes médias por meio da escolarização, as famílias de classe média nutririam esperanças de continuarem sua ascensão social, agora, em direção às elites" (NOGUEIRA; NOGUEIRA, 2002, p. 24).

No que diz respeito aos investimentos das elites econômicas e culturais, Bourdieu (2007) aponta que esse grupo realiza grandes investimentos na escola, porém, de forma "laxista", haja vista que percebe o sucesso escolar como algo que virá naturalmente, portanto, não demanda uma mobilização intensa. Além disso, suas condições objetivas [capitais econômicos, sociais e culturais já adquiridos] fazem com que encarem o fracasso escolar como algo improvável.

É “justamente sobre as formas de transmissão do capital cultural e, por conseguinte, do habitus que incidem as principais críticas à obra de Pierre Bourdieu", afirma Piotto (2009, p. 6). De acordo com Nogueira e Nogueira (2002), no conjunto, as críticas à teoria das classes sociais de Bourdieu expressam que não é possível explicar as posições escolares dos alunos exclusivamente a partir de sua posição de classe, tão pouco o habitus de classe. No tocante à escola, esses autores reforçam e reconhecem os méritos das reflexões desse grande sociólogo, mas apontam também outras limitações:

1 Bourdieu destaca como componentes do esforço para escolarizar a prole: o ascetismo, que se traduz pela disposição dessas classes para renunciarem aos prazeres imediatos em benefício de seu projeto de futuro; o malthusianismo, que diz respeito à propensão de controle de fecundidade; e a boa vontade cultural, que seria caracterizada pelo reconhecimento da cultura legítima e pelo empenho para adquiri-la (NOGUEIRA; NOGUEIRA, 2002). 
O conteúdo escolar não pode ser globalmente definido como sendo um arbitrário cultural dominante. Boa parte dos conhecimentos veiculados pela escola seria epistemologicamente válida e merecedora de ser transmitida [...]. A escola e os próprios professores, dentro delas, não seriam todos iguais. Há variações no modo de organização da escola, nos princípios pedagógicos adotados, nos critérios de avaliação escolar, etc. (p. 33).

Bernard Lahire (1997) também dialogou com o conceito de capital cultural de Bourdieu. Todavia, em outra perspectiva. Através de análises bastante detalhadas, ele trabalhou com os processos concretos de constituição e utilização do habitus familiar. Segundo Piotto (2009), Lahire considera que as trajetórias escolares de sucesso são explicadas a partir de características da organização familiar, mesmo nos casos em que há ausência total ou parcial do capital cultural.

Lahire (1995) observa que é necessário estudar a dinâmica interna de cada família, as relações de interdependência social e afetiva entre seus membros, para se entender o grau e modo como os recursos disponíveis (os vários capitais e o habitus incorporado dos pais) são ou não transmitidos aos filhos. A transmissão de capital cultural e das disposições favoráveis à vida escolar só poderia ser feita por meio de um contato prolongado, e afetivamente significativo, entre portadores desses recursos (não apenas os pais, mas outros membros da família) e seus receptores (NOGUEIRA; NOGUEIRA, 2002, p. 27).

Na obra Sucesso escolar nos meios populares: as razões do improvável, Lahire (1997) oferece contribuições valiosíssimas para a compreensão da dinâmica interna das famílias de estudantes com sucesso escolar improvável, bem como do processo de transmissão cultural. No referido estudo, ele alerta que "a presença objetiva de um capital cultural familiar só tem sentido se esse capital cultural for colocado em condições que tornem possíveis sua "transmissão"” (1997, p. 338). Por esse motivo, mesmo com capital cultural equivalente, duas unidades familiares podem ser produtoras de situações escolares distintas.

Lahire (1997) explora cinco temas relativos às configurações familiares que explicam as trajetórias de sucesso escolar: 
a) Ao abordar as formas familiares de cultura escrita, enfatiza a importância do hábito de leitura, mas salienta que existe nas classes populares uma considerável diversidade de relações com a escrita, mas que estas precisam ser mais bem compreendidas pelos educadores;

b) As condições e disposições econômicas são apontadas como um fator capaz de gerar tranquilidade no universo familiar, embora saliente que "o mesmo capital, a mesma situação econômica podem ser tratados, geridos de diferentes maneiras, e essas maneiras são tanto o produto da socialização familiar de origem e de trajetórias escolares e profissionais, quanto da situação econômica presente" (p. 24-25);

c) A ordem moral doméstica é explicada como uma socialização experienciada segundo princípios de uma moral do bom comportamento, de uma educação para a vida;

d) Ao tratar das formas de autoridade, afirma que elas dizem respeito ao autocontrole e à interiorização das normas de comportamento. Quando vivenciadas legitimamente, contribuem para a aceitação da autoridade escolar;

e) As formas familiares de investimento pedagógico são variadas. Para o estudioso, elas podem tomar formas mais ou menos rigorosas e sistemáticas, bem como operar pautadas em modalidades mais ou menos adequadas, conforme seja o objetivo visado: "incitar a criança a ter 'sucesso' ou a estudar para ter 'sucesso'” (p. 29).

f) Segundo Lahire (1997), o capital cultural é o "princípio socializador mais adequado ou próximo ao mundo escolar" (PIOTTO, 2009, p. 7). Contudo, ele compreende que devemos considerar as diferentes maneiras, formas de relações sociais, a frequência das relações, etc., através das quais o capital cultural ou as disposições culturais se "transmitem" ou não se "transmitem".

Em concordância com Lahire (1997), Bernard Charlot (2000) considera que o espaço familiar não é homogêneo. É um território permeado por uma enorme diversidade de relações e nele a criança constrói sua história singular. Na opinião de Charlot (2000, p. 38), "a sociologia de Bourdieu é perfeitamente legítima [e muito interessante] nos limites em que si fixa". Mas é 'insuficiente' quando trata de casos individuais. "A posição dos filhos não é 'herdada', à maneira de um bem que passasse de uma geração a outra por uma vontade testamental; ela é produzida por um conjunto de práticas familiares: as dos pais [...] e dos filhos" (p. 22). 
Charlot (2000) argumenta que, enquanto pesquisadores, não devemos nos restringir às posições das famílias, mas nos interessarmos também pelas práticas educativas familiares. E, fazendo referência a C. Montandon (1994) reforça que "é impossível deduzir o conjunto das estratégias das famílias ou de suas atitudes para com a escola da classe social à qual pertencem" (p. 21). No exemplo a seguir, retirado do mesmo trecho da obra, compreende-se melhor esta perspectiva:

[...] Duas crianças que pertencem à mesma família, cujos pais têm, portanto, a mesma posição social, podem obter resultados escolares muito diferentes. Essa constatação nos lembra de que uma criança não é apenas "filho de" (ou "filha de"). Ela mesma ocupa uma certa posição na sociedade. Essa posição tem a ver com a dos pais, mas não se reduz a ela e depende também do conjunto das relações que a criança mantém com adultos e outros jovens. A posição da própria criança se constrói ao longo de sua história e é singular.

Diante do exposto, ressaltamos que a partir da Sociologia da Educação de Pierre Bourdieu, tornou-se praticamente impossível analisar as desigualdades escolares, simplesmente, como frutos das diferenças naturais entre os indivíduos. Por sua vez, o percurso feito minimamente até aqui nos estudos de Bernard Charlot e Bernard Lahire nos permite afirmar que o espaço familiar é marcado por uma enorme diversidade de relações. Portanto, o critério de classe social é insuficiente para explicar as diferentes práticas escolares adotadas pelos diversos tipos de grupos familiares.

Por fim, por meio do suporte teórico de Philippe Perrenoud foi possível melhor compreender o peso dos julgamentos escolares na determinação do êxito e do fracasso, o que também facilitou o entendimento acerca da relativa arbitrariedade cultural dos programas escolares e, por conseguinte, das formas e das normas de excelência.

\subsection{A "ditadura" do vestibular}

O sistema Capitalista "ao mesmo tempo promete e nega sucesso escolar, profissional e econômico à maioria da população" (WHITAKER, 2010, p. 290). A ideologia da mobilidade social sugere que "a única maneira de ser bem sucedido em uma 'meritocracia' é conseguir o máximo de escolaridade que se 
possa" (CARNOY, 1986, p. 77). Portanto, não é a toa que desde cedo as nossas crianças já comecem a ser "moldadas para passar no vestibular", pontuou Rubem Alves em entrevista concedida à Revista Cult (2011). Para ele, esse exame é uma "aberração" e existe somente para escolher, dentre os que foram aprovados, aqueles que obtiveram as melhores notas.

O fato é que a partir do $6^{\circ}$ ano do Ensino Fundamental, o estudante já começa a ser treinado para fazer esta prova, ou seja, ele passa quase uma década de sua vida estudando diversas matérias que, na maioria das vezes, não possuem conexão com seu dia a dia, e praticamente só servem de subsídio para o vestibular.

Se por um lado, essa modalidade de ingresso dita o foco dos currículos dos Ensinos Fundamental e Médio, por outro acaba, de certa forma, desprezando o histórico do aluno. Por vezes, encontramos histórias de estudantes que conseguiram boas notas durante toda a sua trajetória escolar e acabaram não conseguindo uma vaga nas universidades, porque no dia da prova ficaram nervosos. Dessa forma, eles se viram obrigados a esperar, às vezes, até por mais de um ano para conseguirem a tão sonhada aprovação. Ressalte-se também que o vestibular potencializa as expectativas familiares, o que deixa o jovem ainda mais ansioso. Sem dúvida, esse alto nível de estresse afeta sua autoestima, tornando o processo de seleção bastante penoso.

Em se tratando de estudantes oriundos da rede pública, a baixa autoestima é vista como um dos maiores causadores da autoexclusão nos vestibulares e no Enem. Os principais argumentos de muitos adolescentes para justificar a falta de interesse pelos exames é a crença de que não são capazes de conseguir bons resultados ou de competir com alunos de outras escolas. "Eles não têm segurança no ensino que recebem. Grande parte não estuda o conteúdo que precisa, não tem professores de várias disciplinas ao longo do ano e sofre com a desorganização curricular da escola. É natural que desacreditem na própria capacidade de chegar ao ensino superior", pontua Mozart Neves Ramos, membro do Conselho de Governança do Todos Pela Educação e do Conselho Nacional de Educação (BORGES, 2011).

\subsection{Breve histórico da admissão aos cursos de graduação no Brasil}

Desde a sua criação, o sistema de seleção à Educação Superior no Brasil converteu-se em um problema complexo, impregnado por barreiras às vezes 
ocultas, mas bastante eficientes. Conforme expôs Cunha (1982), na medida em que se elevou o quantitativo de candidatos aos cursos superiores, por meio desse mecanismo de seleção ora se procurou expandir, ora se procurou conter a demanda. Desse modo, tal como um pêndulo, ele se deslocou da posição de abertura para a de fechamento, atendendo às necessidades políticas e econômicas de diferentes momentos históricos.

Oficialmente, o primeiro instrumento de seleção foi definido pelo Decreto 8.659, de 05 de outubro de 1911, que aprovou a Lei Orgânica do Ensino Superior e do Fundamental, denominada, Reforma Rivadavia Corrêa, que no artigo 65, estabelecia: "Para concessão da matrícula, o candidato passará por um exame que habilite a um juízo de conjunto sobre o seu desenvolvimento intelectual e capacidade para empreender eficazmente o estudo das matérias que constituem o ensino da faculdade". O parágrafo primeiro dessa lei complementava: "O exame de admissão a que se refere este artigo constará de prova escrita em vernáculo, que revele a cultura mental que se quer verificar e de uma prova oral sobre línguas e ciências" (RIBEIRO NETO, 1985, p. 41).

Nos primeiros exames de admissão, realizados na Faculdade de Medicina do Rio de Janeiro, 50\% dos candidatos foram reprovados (CUNHA, 1982). Tal medida, portanto, deixava explícita a intenção de barrar o crescimento "vertiginoso" dos alunos nas escolas superiores, bem como o desejo de recompor a qualidade do ensino pela exclusão prévia dos candidatos que não possuíssem a formação adequada para o ingresso em curso superior.

O exame de admissão nada mais era que um teste de habilitação, através do qual se verificava as condições dos candidatos para os estudos posteriores. "Daí, era exigida uma nota mínima para aprovação", a qual correspondia "a posse de condições intelectuais mínimas para esses estudos” (CUNHA, 1982, p. 7). Esses exames foram extintos em 1925, em razão de outra reforma, a Rocha Vaz. Mas, antes dela, pela Reforma Carlos Maximiliano, em 1915, foram chamados exames vestibulares.

Com a Reforma Rocha Vaz, esse mecanismo de seleção se tornou ainda mais excludente, uma vez que não bastava ser aprovado para ter direito à matrícula no curso superior, era preciso também se classificar entre o número de vagas estabelecido por cada instituição (VALLE; BARRICHELLO; TOMASI, 2010). 
Na prática, a adoção do critério numerus clausus evitava que todos os candidatos que atingissem a nota mínima nos exames pudessem efetivar matrícula, assim como antes ocorria. Contudo, era criada a figura do "aprovado não classificado", ou seja, o "excedente", conforme ressaltou Cunha (1982, p. 11).

Ribeiro (1982, p. 1) também alertou sobre os problemas gerados por esta medida:

A nota mínima exigida, ora não era atingida por um número suficiente de candidatos nas carreiras ou instituições de prestígio, ora era atingida por um número muito grande de candidatos, provocando, no primeiro caso, o abaixamento "a posteriori" da nota mínima e criando, no segundo caso, a figura do excedente.

O vestibular foi utilizado como instrumento de fechamento das oportunidades de acesso ao Ensino Superior até a queda do Estado Novo, em 1945. Segundo Luiz Antônio Cunha (1982), a expansão das matrículas nesse nível de escolaridade foi retomada, após esse período, devido "a combinação de processos econômicos (dependência/monopolização), induzindo a demanda e processos políticos (populismo e depois a busca de base política para o regimento autoritário) induzindo a oferta" (p. 14).

De acordo com Sérgio da Costa Ribeiro (1982), a partir da Lei 4.024/61 - a primeira Lei de Diretrizes e Bases da Educação Nacional - os egressos de qualquer curso médio tiveram mais possibilidades de ingresso no Ensino Superior, haja vista que o exame vestibular muito se assemelhou a um concurso de habilitações. Em concordância, Adolpho Ribeiro Neto (1985) ressaltou que esta LDB foi responsável pela ampliação das oportunidades de ingresso na universidade, uma vez que estabeleceu o princípio de equivalência entre os cursos: secundário tradicional, normal, comercial, industrial e agrícola.

Segundo Whitaker (1983, p. 126), várias medidas contribuíram para tornar o vestibular "um instrumento para distribuição dos candidatos pelos vários cursos e escolas". Cunha (1982) aponta aquelas que mais se destacaram:

I A transferência de recursos financeiros adicionais às escolas superiores, com a finalidade de ampliação das vagas nos vestibulares de 1969 
[Decreto-lei 405/68] e a proibição da diminuição de vagas nos cursos superiores, a não ser com autorização expressa do Conselho Federal de Educação [Decreto-lei 574/69];

II. A adoção de critérios mais brandos para autorização e reconhecimento das escolas superiores particulares;

III. A unificação de vestibulares por região e tipo de curso';

IV. A instituição do "vestibular classificatório"3 [Decreto-lei 68.908/71];

V. A racionalização técnica do processo seletivo ${ }^{4}$, que permitiu a utilização de provas de múltipla escolha e o registro das repostas diretamente em cartões de computador, pelos próprios candidatos.

VI. Esses fatores, dentre outros, alargaram as possibilidades de entrada no Ensino Superior, mas ao mesmo tempo, acirraram as disputas pelas vagas existentes. As palavras de Ribeiro Neto (1982, p. 43) exprimem muito bem esse momento:

[...] a sociedade brasileira experimentava importantes alterações: destacado crescimento demográfico, acelerado processo de organização e industrialização, e maior aspiração por mais educação; [...] contingentes cada vez mais numerosos de candidatos procuraram ingressar nas escolas superiores, notadamente

2 Esses vestibulares unificados por área de conhecimento tinham como pretensão, por um lado, "racionalizar, do ponto de vista do candidato, o acesso a uma vaga, já que com um único exame disputava vagas em várias instituições; do ponto de vista das instituições evitava-se a múltipla matrícula de um mesmo candidato em várias instituições em prejuízo da filosofia dominante de pleno preenchimento de vagas" (RIBEIRO, 1982, p. 2). Dentre esses sistemas unificados destacaram-se: o CESCEM, o MAPOFEI e o CESCEA, em São Paulo, respectivamente para as áreas biológica, tecnológica e humana. Entretanto, acerca de um desses sistemas, Whitaker (2010, p. 292) afirma: "a sigla CESCEM não deve ser vista simplesmente como uma sigla. Na verdade, a criação de um Centro de Seleção de Candidatos das Escolas Médicas foi a primeira tentativa de racionalizar um exame que ia se tornando expressão de ascensão social para um contingente cada vez maior de classes médias em formação e/ou reversão" [grifos nossos].

3 A partir desse critério os candidatos passaram a ser admitidos até o número prefixado de vagas, em ordem decrescente de notas médias, independente da nota mínima. Assim, se resolvia o problema dos chamados "excedentes", haja vista que só eram considerados aprovados aqueles indivíduos cujas notas estivessem dentro do número de vagas, ou seja, não havia candidatos não classificados, e sim, aprovados ou reprovados (CUNHA, 1982). Castro (1982, p. 24), chama a atenção para essa alternativa, segundo ele, "pouco imaginativa": "ao abrir mão da função de estabelecer um limiar de desempenho [nota mínima], dois enormes problemas são criados. Inicialmente, passam a ser admitidos na universidade pessoas com níveis de conhecimento absurdamente baixos: [...] se diante da dificuldade do teste esse conhecimento é ínfimo, os acertos por conhecimento de causa passam a confundir-se com o ruído dos acertos casuais. Isto é, o teste ordena pelo conhecimento; se este inexiste, a ordenação será pela sorte. Portanto, nas áreas onde predominam os candidatos fracos, o vestibular não é capaz de selecionar os melhores - ou menos fracos - transformando-se em uma loteria".

4 As provas objetivas na forma de questões de múltiplas escolhas começaram a ser utilizadas em 1965, em razão dos contingentes crescentes de candidatos. Porém, naquela época, com raras exceções, as provas não seguiam o devido rigor técnico, concentrando-se em exercícios de pura memorização, onde a dificuldade advinha da raridade da informação solicitada (RIBEIRO, 1982). Em contrapartida, esse tipo de prova e de notação de resposta, o "sinal X ou o borrão no espaço indicado, facilitou a obtenção de notas mais elevadas do que as obtidas caso o modo de seleção exigisse demonstrações, cálculos, argumentações, explicitações" (CUNHA, 1982, p. 11). 
naquelas de maior prestígio e que ofereciam as carreiras de maior tradição. Crescia assustadoramente a relação candidato/vaga.

Como ficou demonstrado, a expansão tinha alvos políticos a atingir, embora comprometesse a "qualidade" do ensino superior. Por isso, ao mesmo tempo em que criavam as bases para a expansão, acautelava-se o Estado (CUNHA, 1982). A resistência estatal à ampliação desenfreada do acesso ao nível superior fundava-se em dois fatores: um político e outro ideológico. No plano político, havia o temor de que grandes contingentes de profissionais sem os empregos considerados compatíveis com a dignidade dos seus diplomas se constituísse uma ameaça ainda maior que a dos "excedentes" que se pretendia absorver. Já no plano ideológico, havia o reconhecimento de que "a qualidade do ensino superior estava caindo, formando profissionais incompetentes" (p. 12).

Vejamos como duas categorias profissionais brasileiras se mobilizaram em defesa do valor econômico e simbólico do diploma superior:

A defesa da "qualidade" do ensino superior, pelo freio à expansão empreendida pela burocracia educacional, foi reforçada pelas corporações educacionais ligadas ambas, aliás, por fortes elos de interesses e por quadros comuns. As corporações dos advogados e dos médicos são exemplos de reações diferentes diante do mesmo problema. Os médicos integrantes de uma comissão organizada pelo MEC, em 1973, para estudar a questão do ensino de medicina, propuseram que não se criassem mais escolas nem se expandissem as vagas das já existentes. Menos fortes do que os médicos, portanto menos capazes de imporem mecanismos "internos" de controle, os advogados adotaram um mecanismo "externo": a Ordem dos Advogados submeteria a um exame os concluintes dos cursos de direito, só fornecendo licença para exercer a profissão àqueles que mostrassem conhecimento suficiente para isso (CUNHA, 1982, p. 12).

O descompasso entre o número de ingressantes e a qualidade do ensino ofertado nas instituições também contribuiu para desmerecimento das profissões. Diante das críticas acerca da má formação dos universitários, várias mudanças foram introduzidas, nessa época, para limitar o acesso aos cursos superiores (CASTRO, 1982; CUNHA, 1982; RIBEIRO, 1982; RIBEIRO NETO, 1985), dentre elas: 
I. A segregação dos cursos de curta duração [pelo menos da área tecnológica] para as escolas de $2^{\circ}$ grau [parecer $n^{\circ} 1.589 / 75$ do Conselho Federal de Educação];

II. A adoção de critérios mais rigorosos para a abertura de novos cursos nas instituições particulares ${ }^{5}$;

III. A instituição de etapas eliminatórias nos exames vestibulares, com provas ou questões de redação, seguidas de uma etapa final classificatória.

IV. No que diz respeito à conciliação do critério eliminatório com o classificatório, Cunha (1982, p. 14) critica:

[...] mantêm-se a solução adotada em 1971 para a camuflagem jurídica dos 'excedentes'. Mas essa conciliação parece favorecer mais aos ditames do critério classificatório, pela possibilidade, aberta pelo decreto, de se promover tantos exames vestibulares (também com duas ou mais etapas) quantos sejam necessários para o preenchimento das vagas que sobraram dos primeiros exames.

O aumento dos investimentos em políticas públicas ligadas à expansão de vagas/ instituições de educação superior só voltou a ganhar expressão ao final dos anos 1990. $\mathrm{O}$ alargamento do acesso à universidade tornou-se, então, uma questão premente nas agendas políticas brasileiras, que o apontaram como um dos elementos da estruturação, consolidação e ampliação da democratização da educação em nosso país.

$\mathrm{Na}$ tentativa de fazer um balanço das principais mudanças ocorridas após esse período, será apresentado, a seguir, um conjunto de informações quantitativas e qualitativas decorrentes da implementação da política governamental de ampliação desse nível de escolaridade, com ênfase nos novos mecanismos de avaliação e seleção para ingresso, como o Enem, o Sisu e o Prouni.

Com a aprovação da Lei de Diretrizes e Bases da Educação Nacional - Lei $\mathrm{n}^{\circ}$ 9.394/96 (BRASIL, 1996) abriu-se a possibilidade de diversificação dos processos seletivos para acesso aos cursos de graduação. Nesse sentido, a criação ${ }^{6}$ do Exame Nacional do Ensino Médio [Enem], em 1998, se apresenta como a medida mais expressiva.

5 Não só de medidas duras viveram essas instituições. Devido a grande demanda de candidatos de baixa renda que ocupavam suas vagas, o Estado criou o Programa de Crédito Educativo, direcionado a esses estudantes [assim elas puderam manter seus lucros] (CUNHA, 1982).

6 O Enem foi criado no governo de Fernando Henrique Cardoso, através da Portaria Ministerial $n^{\circ} 438$ de 28 de maio de 1998 (INEP, 2013). 
Até hoje o significado geral dessa iniciativa ainda é muito polêmico e a literatura educacional tem procurado discutir as possíveis implicações dessa prova nacional para a educação brasileira. Sobre a sua criação, o professor João Batista de Oliveira, presidente do Instituto Alfa e Beto, afirmou que o exame teve como propósito "balizar a mal concebida reforma do Ensino Médio de 1997":

A ideia era que todos os alunos cursassem disciplinas de uma pretensa educação geral - e com isso engessamos ainda mais os currículos do ensino médio e também os do ensino técnico: jogamos fora o bebê com a água do banho. O ENEM foi criado para avaliar essas tais "competências da educação geral", completa Oliveira (SCHWARTZMAN, 2010).

Em entrevista a Revista Ensino Superior Unicamp, em 2010, Simon Schwartzman, que atualmente é pesquisador do Instituto de Estudos do Trabalho e Sociedade, comentou que uma peculiaridade do Brasil, na comparação com outros países da América Latina, com a Europa e com os Estados Unidos é o fato de o nosso sistema de Ensino Médio ser praticamente um só. Segundo ele, a diversificação é uma saída para o impasse apresentado anteriormente:

A necessidade de um sistema diversificado tem a ver com os interesses diversificados das pessoas; e também com o fato de que a educação básica é muito desigual, e que nem todas as pessoas têm condições de fazer o mesmo tipo de curso médio. Pelo fato de o modelo ser único - o modelo tradicional, acadêmico, ele mesmo com uma série de problemas específicos -, parte das pessoas não consegue acompanhar o programa e não chega ao final; ou então chega ao final com tantas dificuldades que não tem condições de continuar a estudar e de seguir uma atividade profissional adequada. Temos, assim, um problema de diversificação; e o sistema predominante, que é quase o único que existe, tem vícios e defeitos, decorrentes de seu conteúdo muito formal e do modelo muito antiquado de ensino, enciclopedista. Há uma carga muito grande de cursos em que se pede ao aluno para decorar e repetir certos conteúdos. O sistema não é formativo e está muito condicionado pela competição para a universidade - o que determina o conteúdo dos cursos. Os cursos considerados melhores no ensino médio são aqueles que 
preparam melhor para os vestibulares mais competitivos. Essa formação não é muito adequada.

Para o professor Nilson Machado, da Faculdade de Educação da USP, e um dos idealizadores do exame no formato até 2009, o Enem não foi projetado para ser um processo seletivo, por isso apresenta, atualmente, tantos desvios (FOLHA DE SÃO PAULO, 2012, p. 1):

1) Com a transformação de uma prova de 63 questões em quatro provas, uma para cada área em que se organiza o Ensino Médio, com 45 questões cada uma, o teste ficou excessivamente longo para o conteúdo que examina;

2) A premissa de que a prova deve ser contextualizada, na prática, tem sido tratada como se a palavra "contexto" significasse "com muito texto". Os enunciados são extensos e, na maioria das vezes, o estudante leva um bom tempo até que a resposta correta possa ser encontrada;

3) A utilização da sofisticada Teoria da Resposta ao Item [TRI] na correção das provas é o mais grave de todos os desvios. As limitações na qualidade e na quantidade dos itens dos bancos de questões inviabilizam o sucesso de tal recurso. Sem contar os problemas logísticos: roubos de provas, quebras de sigilo, inadequações na pré-testagem têm se sucedido e afetam significativamente a integridade e a credibilidade da prova.

Acerca da utilização da TRI, o MEC argumenta que as edições do Enem 2009 e 2010 trouxeram um grande diferencial: pela primeira vez foi possível comparar resultados de diferentes edições do exame (WEBER, 2011). Isso aconteceu porque a TRI baseia-se em modelos matemáticos que permitem a elaboração de provas diferentes com o mesmo grau de dificuldade. Anteriormente, não havia como dizer, com segurança estatística, se um eventual aumento das notas médias dos estudantes seria resultado de melhora efetiva na capacidade dos candidatos ou apenas reflexo de uma prova formulada com questões mais fáceis.

Nesse caso, surge uma dúvida: o Enem é uma boa política? Ficará a cargo do leitor deste texto responder a esta questão. Nossa intenção maior não é fornecer as respostas, mas, principalmente, trazer elementos para o debate. Dando continuidade, recorremos, novamente, a contribuição do pesquisador Simon Schwartzman (REVISTA ENSINO SUPERIOR UNICAMP, 2010): 
O Enem foi uma tentativa de estabelecer um padrão de referência. Pode-se criticá-lo - há tantos problemas no Enem atual quanto no anterior. Mas a ideia de haver padrões claros de referência é o importante. (...) Mas, de novo, se a referência for única, mata a diversificação. É preciso criar uma gama de alternativas, todas com avaliações também independentes, também externas, mas não únicas.

Ao longo de suas quinze edições (1998-2013), o Enem se propôs a diferentes funções. Atualmente, a nota obtida no exame pode ser usada:

como requisito básico para disputar uma das vagas oferecidas pelo Sistema de Seleção Unificada (Sisu), que seleciona estudantes para as universidades federais, estaduais e institutos de tecnologia;

como substituição à primeira fase do vestibular ou como complemento da nota nas instituições públicas que não aderiram ao Sisu;

para concorrer a uma vaga no Programa Universidade para Todos (Prouni), que oferece bolsas de estudo em instituições de ensino superior privadas a estudantes de baixa renda.

Além disso, o Enem é obrigatório:

- para quem deseja solicitar ajuda do Fundo de Financiamento do Estudante do Ensino Superior (Fies) para o pagamento das mensalidades em cursos oferecidos por instituições privadas;

- para universitários interessados em estudar no exterior, através do Programa Ciências sem Fronteiras;

- para quem tem mais de dezoito anos e deseja obter o certificado de conclusão do Ensino Médio por meio da nota da prova.

Na medida em que o Enem foi ganhando importância, o número de participantes também aumentou. Em sua primeira edição, em 1998, 157.221 pessoas se inscreveram. Desde então, os números cresceram gradativamente, atingindo o patamar de 7.173.574 inscritos na maior edição do exame, realizada em 2013. 
Gráfico 1 - Evolução dos inscritos no Enem - 1998 a 2013

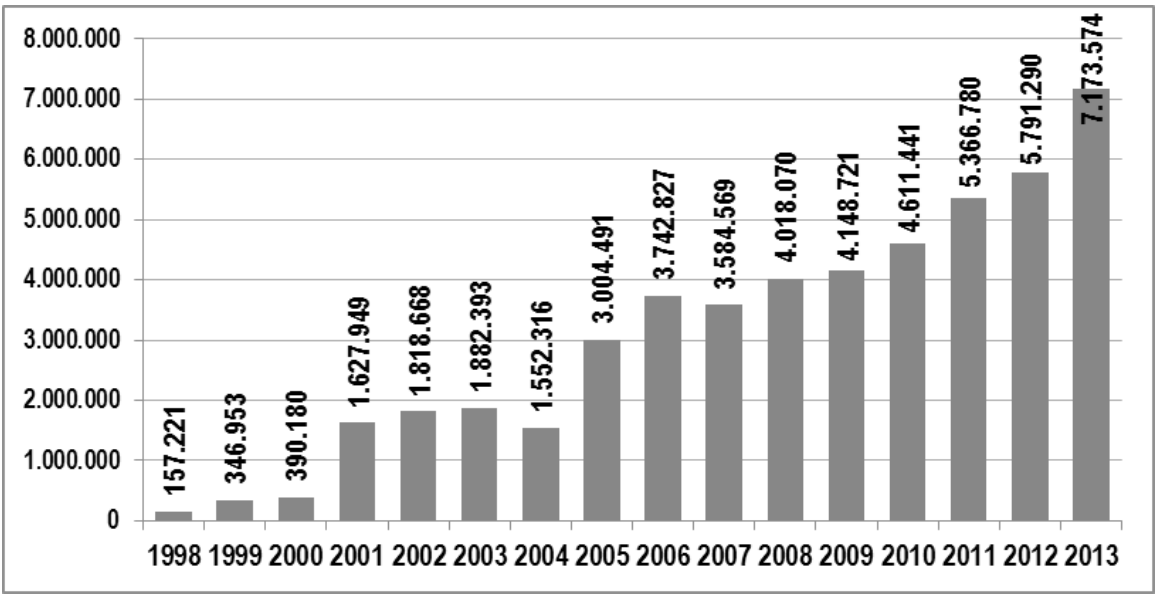

Fonte: INEP (2013).

De fato, o Enem se tornou o maior "vestibular" do Brasil. E isso aconteceu mediante vários acertos, erros e confusões:

a) Em 2001, uma medida importante para democratizar o Enem foi a isenção do pagamento da taxa de inscrição para os alunos de escolas públicas.

b) Em 2004, com a criação do Programa Universidade para Todos (Prouni), estudar em instituições privadas sem pagar a mensalidade [ou parte dela] tornou-se um grande atrativo para os estudantes.

Como já dissemos a seleção ${ }^{7}$ para as bolsas do programa se dá a partir dos resultados obtidos no Enem. Para isso, é necessário que o candidato obtenha 400 pontos no exame, bem como possua renda per capita de até um salário mínimo e meio [para concorrer às bolsas integrais] ou renda de até três salários mínimos [para concorrer às bolsas parciais, de $50 \%$ e $25 \%$ ]. Além disso, é requisito que o aluno tenha cursado o Ensino Médio integralmente ou parcialmente em escola pública, ou em escola particular, na condição de bolsista integral ou parcial (MEC, 2013).

7 O MEC recebe as inscrições para o programa por meio de um sistema disponível na internet, o Sisprouni. E uma comissão, constituída pelo referido Ministério, tem a responsabilidade de conferir os perfis dos candidatos, bem como divulgar a lista dos pré-classificados. Após a publicação da lista, os classificados procuram às instituições para as quais conseguiram o benefício para confirmar seus dados, levando a documentação comprobatória. Somente após a análise da documentação pela IES o benefício é liberado. 
De acordo com dados divulgados pelo Ministério da Educação, em seu primeiro ano de funcionamento, o programa ofereceu 112.275 bolsas de estudo em 1.142 instituições de todo o país. O quantitativo atualizado de bolsistas beneficiados pode ser observado no Gráfico 2:

\section{Gráfico 2 - Bolsas do Prouni ofertadas por ano - Brasil - 2005 a 2013}

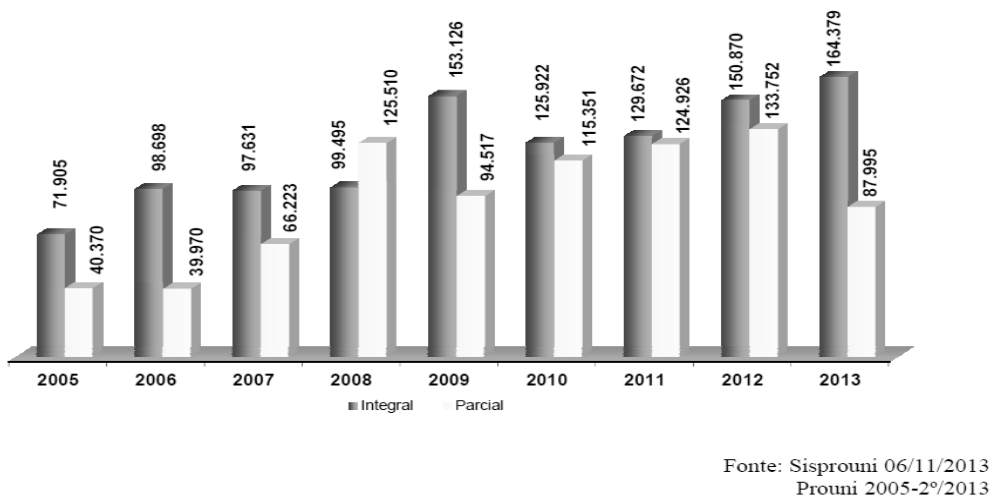

Fonte: Sisprouni (2013); Prouni - 2005/2 2013 (MEC, 2013).

Institucionalizado pela Lei 11.096, de 13 de janeiro de 2005 (MEC, 2013), o Prouni veio acompanhado por um forte discurso de "justiça social" e contou com o apoio da sociedade civil. Contudo, para muitos estudiosos (MANCEBO, 2004; CATANI, HEY, GILIOLI, 2006; CARVALHO, 2006a, 2006b; ZAGO, 2006) o programa promove uma democratização "às avessas" e representa a intensificação do processo de estatização das vagas nas instituições privadas por meio da transferência de recursos públicos.

Pesquisadores e analistas de políticas públicas também alertam para a falta de mecanismos de controle democrático do Programa. De acordo com Valente e Helene (2004) apud Catani, Hey e Gilioli (2006, p. 136): “o que o Prouni faz é aumentar as isenções fiscais para IES privadas que, com poucas exceções, não prestam conta de como as usam, remuneram de forma ilegal seus sócios, não têm transparência na concessão de bolsas e maquiam balanços".

De acordo com matéria de Rafael Targino (UOL, 2011), uma em cada três bolsas oferecidas desde o começo do programa, em 2005, não foi preenchida. O total de 
bolsas ociosas chegou a 427.438 em seis anos, o que equivale a 33,1\% de todas elas. A reportagem afirma ainda que, em 2009, uma análise do TCU [Tribunal de Contas da União] estimou que pudesse ter sido perdido, só nos dois primeiros anos do programa, um valor em torno de $\mathrm{R} \$ 100$ milhões. Até o primeiro semestre de 2011, o Prouni funcionava por meio de isenção fiscal em relação às bolsas oferecidas. Neste sentido, se a universidade oferecesse 100 bolsas, a redução nos impostos seria relativa a todas, mesmo que não fossem totalmente preenchidas. Isso demonstra que, neste período, o governo verdadeiramente perdeu dinheiro.

Outra falha do Prouni apontada pelo relatório do TCU diz respeito à baixa procura pelos alunos beneficiados por cursos das áreas tecnológica e social, considerados prioritários por terem poucos profissionais em atuação. Com o intuito de que os problemas citados sejam superados, o tribunal recomendou ao MEC que faça um controle melhor dos alunos beneficiários do programa, bem como reavalie a concessão da isenção fiscal dada às instituições de ensino e que a Secretária de Educação Superior (Sesu/MEC) implemente mecanismos para o preenchimento total das vagas ofertadas e incentive os estudantes a fazerem cursos das áreas tecnológica e social (AGÊNCIA BRASIL, 2009).

O Prouni está completando 10 anos mediante avanços e críticas. Por um lado, ele é celebrado por muitos estudantes e suas famílias, mas por outro, possui problemas que não aparecem nas principais estatísticas nem nas propagandas em vídeo com modelos sorridentes, citamos a seguir algumas deles:

A questão da má qualidade ${ }^{8}$ de alguns cursos:

Em alguns casos, o acesso à universidade via Prouni pode não ser tão vantajoso: um cruzamento feito pela reportagem daAgência Estado (UOL, 2009) com dados do IGC [Índice Geral de Cursos] - anunciado pela primeira vez em setembro de 2008 e que permitem comparar o desempenho das IES - 22,9\% das instituições que ofereceram vagas no programa apresentaram desempenho 1 e 2 , o que pode ser traduzido como cursos com baixa ou baixíssima qualidade. Num universo de 991 instituições integrantes do programa em 2008, 227 tiveram desempenhos insatisfatórios. Em

8 De modo geral [e não específico das instituições que adotam o Prouni], o problema da equidade no acesso aos cursos de qualidade existe e é muito grave. Na opinião de Schwartzman (2009): "existem universidades boas, cursos de graduação e programas de pós-graduação de boa qualidade, mas muita coisa - possivelmente a maior parte - é de má qualidade. Nem tudo que se chama de 'universidade', ou 'universitário' mereceria realmente este nome. O mercado profissional estaria sendo invadido por profissionais incompetentes". 
2011, dentre as 1.875 instituições, 551 delas obtiveram desempenho baixo (menor que 3). Outras 261 não tiveram conceito no MEC (MATSUKI, 2012).

Segundo Carvalho (2006b, p.995-996):

[...] o programa pode trazer o benefício simbólico do diploma àqueles que conseguirem permanecer no sistema e, talvez, uma chance real de ascensão social para poucos que estudaram no seleto grupo de instituições privadas de qualidade. Mas, para a maioria, cuja porta de entrada encontra-se em estabelecimentos lucrativos e com pouca tradição no setor educacional, o programa pode ser apenas uma ilusão e/ou uma promessa não cumprida.

Nesta mesma linha de pensamento, Corbucci (2004, p. 694), afirmou:

A principal crítica dirigida a essa iniciativa governamental é a de que os recursos que deixarão de ser arrecadados com a isenção de impostos poderiam ser aplicados na ampliação da oferta de vagas nas instituições públicas. Portanto, para alguns críticos da proposta, o Estado estaria comprando vagas já existentes e ociosas, e ao mesmo tempo oferecendo um serviço de qualidade duvidosa.

A questão da permanência até o final da graduação:

Muitos bolsistas enfrentam dificuldades para custear os gastos extras surgidos ao longo do curso superior. Nesse sentido, não há controle do MEC sobre esta e outras questões que levam ao abandono - o órgão não informa o número de desistências. Ao mesmo tempo, na campanha da TV, o programa é exaltado pela capacidade de "garantir o diploma", embora o mais correto fosse "garantir o acesso", uma vez que o caminho até a conclusão do curso apresenta obstáculos nem sempre possíveis de serem transpostos por estudantes vindos de classes menos favorecidas.

Atualmente, é oferecida a bolsa permanência para quem tem bolsa integral em um curso presencial com duração mínima de seis semestres e carga horária média igual ou superior a seis horas diárias. Esse benefício equivale ao praticado na política federal de bolsas de iniciação científica, cujo valor é de $\mathrm{R} \$ 400,00$. A bolsa permanência ajuda, mas não é o suficiente, pois a vida universitária ultrapassa os portões de entrada e os gastos vão além da matrícula e da mensalidade: há 
despesas com livros, materiais, transporte, alimentação e até moradia. Em alguns cursos existem também gastos específicos, como, por exemplo, no curso de arquitetura, em que o aluno precisa de materiais para fazer trabalhos e maquetes.

Para concluir esta discussão sobre o Prouni, deixamos no ar um questionamento que ultrapassa os limites desse texto, mas que precisa ser encarado: o programa potencializou as chances de nossa juventude de se profissionalizar e garantir seu futuro?

Trago para o debate um alerta: especialistas apontam para a decepção do mercado com o que já está sendo chamado de "geração do diploma". "Os empresários não querem canudo. Querem capacidade de dar respostas e de apreender coisas novas. E quando testam isso nos candidatos, rejeitam a maioria", afirmou o sociólogo e especialista em relações do trabalho da Faculdade de Economia e Administração da USP, José Pastore (COSTAS, 2013). Estudiosos consultados pela reportagem da BBC Brasil também disseram que a principal causa para a decepção com a "geração do diploma" estaria relacionada à qualidade do ensino e habilidades dos alunos que se formam em algumas faculdades e universidades do país.

De volta aos acertos, erros e confusões envolvendo o Enem:

a) Em 2010, o Enem passou a servir como uma espécie de "vestibular nacional".

Através do Sistema de Seleção Unificada (Sisu), ferramenta online que cruza os dados das vagas nas instituições de ensino com as notas dos alunos no Enem, é possível, por meio de apenas uma inscrição, pleitear vagas em instituições públicas de todo o país.

Desde a criação desse sistema unificado, a ideia do MEC era que o Enem substituísse os vestibulares. Por isso, com a adesão de grandes universidades, isso acabou ficando mais perto de se efetivar. $\mathrm{Na}$ lista das dez maiores federais, apenas duas ainda resistem em aderir ao Sisu: a Federal do Rio Grande do Sul (UFRGS) e a Federal de Pernambuco (UFPE) 9 . A adesão ao sistema já uma realidade na: Federal da Bahia (UFBA), Federal do Pará (UFPA), Universidade de Brasília (UnB) ${ }^{10}$, Federal da Paraíba (UFPB), Federal de Minas Gerais

9 No vestibular 2014, a UFPE manteve o Enem, incluindo a redação, como a primeira etapa e as provas específicas, aplicadas pela instituição, como a segunda fase. Já na UFRGS, a partir de $2015,30 \%$ das vagas serão distribuídas por meio do processo seletivo gerenciado pelo MEC. O restante delas continuará sendo ofertada pelo vestibular da instituição.

10 Em 2013, a UnB confirmou a adesão ao Sisu com o fim do vestibular de verão. No entanto, optou por manter a seleção de inverno e o programa de avaliação seriada. 
(UFMG), Federal Fluminense (UFF), Federal do Rio de Janeiro (UFRJ) e Federal do Rio Grande do Norte (UFRN).

Considerando apenas as demais universidades federais e estaduais e os institutos de tecnologia da Região Nordeste, a adesão à prova do Enem foi quase total ${ }^{11}$ :

Tabela 1 - Instituições do NE que aderiram ao Sisu

\begin{tabular}{ll}
\hline Estado & Instituição \\
\hline Alagoas & UFAL, IFAL \\
\hline Bahia & UFBA, UFRB, UESB,UESC, UNEB, IFBA, IF BAIANO \\
\hline Pernambuco & UFRPE,UNIVASF, IFPE, IFPE, IF SERTÃO \\
\hline Ceará & UFC, IFCE, UNILAB \\
\hline Maranhão & UFMA, IFMA \\
\hline Paraíba & UFPB, UEPB, UFCG, IFPB \\
\hline Piauí & UFPI, UESPI, IFPI \\
\hline Rio Grande do Norte & UFRN, IFRN, UFERSA \\
Sergipe & UFS, IFS \\
\hline
\end{tabular}

Fonte: VEJA (2012).

Apesar do elevado número de inscritos e do apoio de várias instituições, o Sistema de Seleção Unificada apresenta problemas e precisa de mudanças. Selecionamos algumas situações para refletirmos:

\section{3 Evasão tem aumentado com o Sisu.}

Segundo a reitora Maria José de Sena, da UFRPE, o índice de alunos que abandona o curso na Rural dobrou. Passou de $15 \%$ para uma média de $30 \%$. Ela salienta que este "não é um problema só na UFRPE. É nacional. Todas as universidades que integram o Sisu têm percebido mais evasão. Tanto que a questão tem sido discutida com o MEC". Na opinião da reitora, "a maioria dos candidatos não entra no curso que tem vocação. Como o sistema permite que ele busque vaga pela nota, termina ingressando numa graduação que não é a sua primeira ou segunda opção" (JORNAL DO COMMERCIO, 2014).

11 O Sisu substitui a $1^{\text {a }}$ fase do vestibular da UFPE e UPE e completa a nota do vestibular da UERN. Porém, não é usado nas seguintes instituições: UECE, UEMA, UNEAL e UNCISAL. 
Com o maior número de inscritos no Sisu 2012, o curso de tecnologia em gestão pública do Instituto Federal de Brasília (IFB) registrou uma evasão superior a $50 \%$ no último semestre daquele ano. Segundo o coordenador do curso, Ailton Bispo, dos 30 alunos que ingressaram, somente 12 concluíram o período. "A gente percebeu que muitos não sabiam o que era o curso, acabavam descobrindo lá dentro. Isso ajuda a explicar a alta evasão" (G1, 2013). Para ele, a taxa de reprovação também é consequência do alto nível do curso, que tem disciplinas como cálculo, estatística, planejamento urbano e direito tributário:

O nosso curso exige muita dedicação, é um curso bastante puxado. A gente investe pesadamente em disciplinas aplicadas. Mas, em compensação, o nosso aluno termina em condição de atuar em órgãos do setor público, bem como iniciar um mestrado, se quiser. Eles têm uma boa noção de tudo. Saem profissionais completos, completa Ailton Bispo (G1, 2013).

Como solução para o problema da evasão, a reitora Maria José defende uma mudança no formato da inscrição do Sisu. Atualmente, o estudante escolhe dois cursos e duas universidades e pode mudar de acordo com o ponto de corte, durante o período de inscrição. Na opinião dela, o candidato deveria se inscrever em apenas um curso e indicar duas instituições. Nesse caso, acabaria a consulta ao ponto de corte. Essa proposta, segundo ela, foi apresentada ao MEC. "Vai ser formada uma comissão com vários reitores para aprofundar o debate" (JORNAL DO COMMERCIO, 2014).

\subsection{Acesso difícil às carreiras mais concorridas do Sisu.}

Dentre as vinte carreiras com maior nota de corte da primeira edição do Sisu 2014, catorze eram engenharias. A plataforma digital do MEC registrou que a maior nota foi detectada no curso de Engenharia Naval, da Universidade Federal do Pará: 869,15 na ampla concorrência. Entre os cotistas ${ }^{12}$, a maior nota do curso foi 746,44 (O ESTADÃO, 2014).

12 A Lei $n^{\circ} 12.711$, de 29 de agosto de 2012, garante a reserva de $50 \%$ das vagas, por curso e turno nas 59 universidades federais, nos 38 institutos federais de educação, ciência e tecnologia e nos 2 centros federais de educação tecnológica, a estudantes que tenham cursado o ensino médio em escolas públicas. Há instituições participantes do Sisu que disponibilizam, ainda, uma parte de suas vagas para políticas afirmativas próprias. Assim, em determinados cursos, pode haver três modalidades de concorrência: vagas de ampla concorrência, vagas reservadas de acordo com a Lei de Cotas e vagas destinadas às demais ações afirmativas da instituição. Ressalte-se que, de acordo com a Lei $n^{\circ} 12.711 / 2012$, a reserva de vagas pode ser implementada gradualmente. Por isso, cada instituição pode optar pelo percentual a ser reservado, garantindo, no processo seletivo do Sisu 1\%/2014, pelo menos $25 \%$ de suas vagas para as cotas. Até 2016, as instituições deverão atingir o percentual de $50 \%$ de vagas reservadas (SISU, 2014). 
Por sua vez, o curso de Arquitetura e Urbanismo, do Instituto Federal de Educação, Ciência e Tecnologia de São Paulo, foi o curso mais concorrido entre as instituições superiores que ofertaram 100\% das vagas pelo Sisu 2014. Cada vaga foi disputada por 312,55 candidatos. Em segundo lugar, veio o curso de medicina da Universidade Federal do Acre, com 210,35 candidatos por vaga. Neste ano, a relação candidato vaga total dos cursos de ampla concorrência foi de 27,19. Já a concorrência enfrentada pelos inscritos pela lei de cotas foi maior: 31,76 candidatos disputavam cada vaga. Entre aqueles que concorreram por meio de vagas ofertadas por ações afirmativas foi de 30,35 (O ESTADÃO, 2014).

Para os que defendem esse sistema, ele é um processo de acesso democratizado pelo mérito do estudante. Já na opinião da professora Ana Paula Hey (2009), da USP, o Enem não muda a realidade que é marcada pela desigualdade de oportunidades. Para a especialista em Políticas Públicas de Educação, "se os vestibulares unificados anteriores eram excludentes, utilizar o Enem não quebra essa lógica" (p. 01).

Em concordância, a pedagoga Sandra Zákia Sousa, da Universidade Cidade de São Paulo [UNICID] e colaboradora da USP, "o Enem dificilmente terá potencial de alterar as chances de ingresso dos menos favorecidos ao ensino superior. Portanto, não é por meio dele que se produzirá maior justiça" (MANIR, 2009, p. 1). O pedagogo Ocimar Alavarse (ISTO É, 2011) também compartilha dessa opinião, embora seja mais taxativo ao falar da probabilidade de ingresso de alunos de nível socioeconômico mais baixo em cursos concorridos:

[O Enem] é uma ilusão. O aluno pode tentar [o acesso] em 15 universidades, mas, pela qualidade da educação que recebeu, não vai conseguir entrar para os cursos mais concorridos de nenhuma delas. [o Enem não democratizou o acesso ao ensino superior]. Se nós tivéssemos igualdade de chances, eu não teria problemas com o Enem. Mas não temos (p. 1).

A mobilidade acadêmica é uma das bandeiras do Enem. Essa "mobilidade" está no fato do estudante poder escolher até duas opções de curso entre as vagas ofertadas pelas instituições participantes do Sisu. Porém, o que é mostrado como uma grande "revolução" no ensino superior brasileiro, na prática, revela uma situação ainda mais agressiva e desigual. Os melhores alunos de todos os 
estados irão para as melhores universidades do país, restando para os demais, cursos distantes de casa ou fora de sua preferência. Muitos deles, mesmo aprovados, nem irão para a universidade.

O acesso à graduação, nesse caso, está relacionado ao número de pontos obtidos no Enem e à quantidade de vagas que o curso da preferência do estudante possui. Ou seja, não muito diferente do que sempre foi visto no vestibular. Em outras palavras, a lógica do mercado presente nesse tipo de prova permanece na política atual do governo, pois os alunos que não tiveram um ensino voltado para esse tipo de seleção continuarão em condições menos favoráveis para ingressar no ensino superior.

Pelo visto, não é tão fácil acabar com essas coisas burocráticas, que não têm a ver com educação. $\mathrm{O}$ educador Rubem Alves, 78 anos, na sua entrevista de despedida da coluna que escrevia semanalmente para o jornal Folha de São Paulo, alegou que gastou muito tempo da sua vida lutando para acabar com o vestibular. Obviamente, ele não conseguiu; outros que também tentaram não conseguiram, mas, certamente, ficou o legado de todos eles. Encerro com um convite para um novo debate: O que o Enem pode fazer em prol do Ensino Médio?

Veja bem: se eu fizer vestibular ou Enem, serei reprovado. Todos os reitores das universidades seriam reprovados. Há uma frase que repito e acho importante: a educação acontece depois que o esquecimento fez o seu trabalho. De modo que eu gostaria que o exame fosse feito somente um ano depois de o aluno terminar seus estudos, para saber realmente o que ficou. E o que sobra do ensino médio hoje, em geral, é nada. A coisa mais importante para mim não é o exame em si, mas o que esses exames fazem com tudo que vem antes. (...) passar no vestibular é a ideia que passou a ser dominante em nossa educação. Os pais são os maiores inimigos da educação porque não sabem o que ela é. Acham que é preparar para os exames. E aí você elimina a poesia, as artes, tudo aquilo que faz parte da verdadeira educação, mas que é eliminado pelos próprios exames.

Quando fui pró-reitor de graduação na Unicamp, organizei uma série de encontros na universidade para saber dos professores o que eles achavam que seria um sistema justo para a admissão nos cursos. Mas isso não existe. Todos 
são defeituosos de alguma maneira porque alteram tudo que vem antes. Eles predeterminam os programas que vão ser dados nas escolas. Lembro que um dos professores chegou para mim com uma risadinha na boca e disse: "Tenho um sistema muito simples: sorteio". Achei absurdo, mas depois comecei a pensar que acabaria com os cursinhos pré-vestibular e as escolas ficariam livres para ensinar as coisas que são essenciais para a educação (REVISTA CULT, 2011).

\section{Considerações finais}

A formação universitária é cada vez mais exigida como condição de empregabilidade e de inserção na vida social. Todavia, o nível de escolaridade da população brasileira é baixo e desigual. Muitas instituições públicas de Educação Básica escolarizam as pessoas com insuficiências em aprendizagens fundamentais, como leitura, escrita e matemática, por exemplo. O que em grande parte favorece a eliminação precoce dos estudantes oriundos dos meios menos favorecidos.

A legitimidade do mérito, portanto, exerce uma dupla ação: para os que alcançaram êxito nos mecanismos de seleção, o resultado é considerado justo, sendo compensado pela conquista de uma vaga na IES e pelo reconhecimento por parte das pessoas. Para aqueles que não obtiveram sucesso, o mau resultado é considerado merecido, pois todos são levados a crer que os candidatos tiveram oportunidades iguais, mas somente os melhores souberam aproveitá-las, se prepararam adequadamente e se esforçaram.

O fato é que os nossos mecanismos de admissão ao ensino superior têm funcionado como "uma fita de chegada, que deve ser rompida numa maratona", alertou Ribeiro Neto (1985, p. 48). Nesse sentido, segundo o estudioso, é ilusório pretender-se que "ela possa ser igualmente justa para todos os competidores, que, na verdade, partem de marcas diversas, às vezes muito distanciadas entre si, e quase sempre percorrem caminhos distintos" (p.48).

Concordamos em grande medida também com o professor de Economia, Cláudio de Moura Castro (1982, p. 26), quando o afirma que "o acesso à universidade se determina nos níveis anteriores". Logo, abrem-se mais as portas das melhores universidades brasileiras quanto mais bem preparados forem os egressos do Ensino Médio. 


\section{Referências}

AGÊNCIA BRASIL. Relatório do TCU aponta irregularidades na concessão de bolsas do ProUni. Extra Online/globo.com. 2009. Disponível em: < http:// extra.globo.com/noticias/brasil/relatorio-do-tcu-aponta-irregularidades-naconcessao-de-bolsas-do-prouni-271923.html>. Acesso em: 18 jul. 2011.

BARDIN, L. Análise de conteúdo. São Paulo: Livraria Martins Fontes, 1977.

BORGES, P. Baixa autoestima afasta alunos de públicas do Enem. iG Brasília. 2011. Disponível em: <http://ultimosegundo.ig.com.br/educacao/enem/baixaautoestima-afasta-alunos-de-publicas-do-enem/n1597208093056.html>. Acesso em: 04 dez. 2011.

BOURDIEU, P. A Escola conservadora: as desigualdades frente à escola e à cultura. In: NOGUEIRA, M. A.; CATANI, A. (Org.). Escritos de educação. 9. ed. Petrópolis, RJ: Vozes, p. 39-64, 2007.

BRASIL. Lei $\mathrm{n}^{\circ}$ 9.394, de 20 de dezembro de 1996. Estabelece as diretrizes e bases da educação nacional. Diário Oficial da União, Brasília, DF, 23 dez. 1996. Disponível em: < http://www.planalto.gov.br/ccivil_03/leis/L9394.htm>. Acesso em: 04 abr. 2011.

CARNOY, M. Educação, economia e Estado: base e superestrutura: relações e mediações. São Paulo: Cortez, 1986.

CARVALHO, C. H. A. Política para o Ensino Superior no Brasil (1995-2006): ruptura e continuidade nas relações entre público e privado, 2006a. Disponível em: $\quad<$ http://www.anped.org.br/reunioes/29ra/trabalhos/trabalho/GT11-2337-Int.pdf $>$. Acesso em: 07 ago.2011.

. O PROUNI no governo Lula e o jogo político em torno do acesso ao Ensino Superior. Educação e Sociedade, Campinas, v. 27, n. 96, Especial, out., p. 979-1.000, 2006b. Disponível em: <http://www.cedes.unicamp.br>. Acesso em: 08 ago. 2011.

CASTRO, C. de M. Sua Excelência, o Vestibular. Fórum de debates - Em Aberto, ano 1, n. 3, Brasília, DF, 1982. Disponível em: <www.rbep.inep.gov. br/idex.php/emaberto/issue/view/128/showToc >. Acesso em: 10 set. 2011. 
CATANI, A. M.; HEY, A. P.; GILIOLI, R. S. P. PROUNI: democratização do acesso às Instituições de Ensino Superior? Educar em Revista, Paraná, n. 28, dez., p. 125-140, 2006.

CHARLOT, B. Da relação com o saber: elementos para uma teoria. Porto Alegre: Artes Médicas Sul, 2000.

CORBUCCI, P. R. Financiamento e Democratização do Acesso à Educação Superior no Brasil: da deserção do Estado ao projeto de reforma. Educação e Sociedade, Campinas, v. 25, n. 88, Especial, p. 677-701, out., 2004.

COSTAS, R. Geração do diploma lota faculdades, mas decepciona empresários. BBC Brasil, 2013. Disponível em: < http://www.bbc.co.uk/portuguese/ noticias/2013/10/131004_mercado_trabalho_diplomas_ru.sshtm>. Acesso em: 07 dez. 2013.

CUNHA, L. A. Vestibular: a volta do Pêndulo. Fórum de debates - 'Em Aberto', ano 1, n. 3, Brasília, fev., 1982. Disponível em: <www.rbep.inep.gov.br/idex. php/emaberto/issue/view/128/showToc $>$. Acesso em:10 set. 2011.

FOLHA DE SÃO PAULO. A loteria Enem. São Paulo, 2012. Disponível em: $<$ http://www.andifes.org.br/index.php?option $=$ comcontent\&view $=$ article\&id $=6155$ :a-loteria-enem- $\&$ catid=508Itemid=100017 >. Acesso em: 20 jan. 2012.

GIZI, M. L. Políticas educacionais para a educação superior: acesso, permanência e formação. Revista Diálogo Educacional, Curitiba, v. 4, n. 11, jan./abr., p. 43-52, 2004.

G1. $1^{a}$ turma do curso mais procurado no Sisu tem evasão superior a 50\%. 2013. Disponível em: $<$ http://g1.globo.com/distrito-federal/noticia/2013/01/1-turmado-curso-mais-procurado-no-sisu-tem-evasao-superior-50.html $>$. Acesso em: 25 jan. 2013.

HEY,A.P. Notícias da UFMG: Professora da USP questiona Enem como forma de democratização do acesso à universidade. In: Semana de conhecimento e cultura da UFMG. 2009. Disponível em: <www.ufmg.br/online/arquivos/013510. shtml>. Acesso em: 14 set. 2011. 
INEP. Sítio do Enem. 2013. Disponível em: <http://portal.inep.gov.br/web/ enem/enem>. Acesso em: 23 jan. 2013.

ISTO É. O Enem não democratizou o acesso ao ensino superior. 2011. Disponível em: $\quad<$ http://www.andifes.org.br/idex.php?option=com content $\&$ view $=$ article $\&$ id $=5865$ : qo-enem-nao-democratizou-o-acesso-aoensino-superiorq-\&catid=61\&Itemid=100015>. Acesso em: 20 out. 2011.

JORNAL DO COMMERCIO. Evasão na UFRPE aumenta com o Sisu. 2014. Disponível em: < http://jconlineblogs.ne10.uol.com.br/blogdofera/2014/01/19/ evasao-na-ufrpe-aumenta-com-o-sisu/>. Acesso em: 25 jan. 2014.

LAHIRE, B. Sucesso escolar nos meios populares: as razões do improvável. São Paulo: Ática, 1997.

MANCEBO, D. Reforma universitária: reflexões sobre a privatização e a mercantilização do conhecimento. Educação e Sociedade, Campinas, v. 25, n. 88, Especial - out., 2004.

MANIR, M. Um funil de incertezas. O Estadão. 2009. Disponível em: <www. estadao.com.br/noticias/suplementos,um-funil-de-incertezas, $449166,0 . \mathrm{htm}>$. Acesso em: 16 set. 2011.

MATSUKI, E. MEC anuncia suspensão de vestibular para 207 cursos reprovados em avaliação. UOL. 2012. Disponível em: <http://educacao.uol. com.br/noticias/2012/12/18/mec-anuncia-suspensao-de-vestibular-para-207cursos-reprovados-em-avaliacao.htm>. Acesso em: 28 dez. 2012.

MEC. Ministério da Educação. Site do Prouni. 2013. Disponível em: < http:// prouniportal.mec.gov.br/index.php>. Acesso em: 22 jan. 2014.

NOGUEIRA, C. M. M.; NOGUEIRA, M. A. A sociedade da educação de Pierre Bourdieu: limites e contribuições. Educação \& Sociedade, Campinas, ano 23, n. 78, p.15-36, abr., 2002.

O ESTADÃO. Entre os 20 cursos com maior nota de corte do Sisu, 14 são engenharias. 2014. Disponível em: < http://www.estadao.com.br/ noticias/vidae, entre-os-20-cursos-com-maior-nota-de-corte-do-sisu-14-saoengenharias, 1118072,0.htm>. Acesso em: 24 jan. 2014. 
PERRENOUD, P. A avaliação no princípio da excelência e do êxito escolares. In: Avaliação: da excelência à regulação das aprendizagens - entre duas lógicas. Porto Alegre: Artes Médicas Sul, 1999.

- Sucesso na escola: só o currículo, nada mais que o currículo! $10^{\circ}$ Colégio da Association des Cadres Scollaires du Québec - ACSQ - Québec, 27 a 29 de nov. de 2002. Trad. N. L. Rezende. Cadernos de Pesquisa, São Paulo, n. 119, jul., p. 9-27, 2003.

PIOTTO, D. C. A escola e o sucesso escolar: algumas reflexões à luz de Pierre Bourdieu. 2009. Disponível em: <www.ufsj.edu.br/portal- /file/vertentes/ debora_piotto.pdf $>$. Acesso em: 09 ago. 2011.

REVISTA CULT. Entrevista Rubem Alves. 2011. Disponível em: < http:// revistacult.uol.com.br/home/2013/01/\%E2\%80\%9Co-vestibular-e-umaaberracao\%E2\%80\%9D>. Acesso em: 03 jan. 2014.

REVISTA ENSINO SUPERIOR UNICAMP. Entrevista/Simon Schwartzman. 2010. Disponível em: $<$ http://www.gr.unicamp.br/ceav/revistaensinosuperior/ed02 novembro2010/pdf/Ed02_novemnov2010_entrevista.pdf $>$. Acesso em: 03 set. 2011.

RIBEIRO, S. C. O Vestibular. Fórum de debates - Em Aberto, Brasília, DF, ano 1, n. 3, fev., 1982. Disponível em: <www.rbep.inep.gov.br/index.php/emaberto/ issue/view/128/showToc $>$. Acesso em: 10 set. 2011.

RIBEIRO NETO, A. O vestibular ao longo do tempo: implicações e implicâncias. Seminário "Vestibular Hoje”. Brasília, DF: MEC/SESU/CAPES, 1985. Disponível em: <www.fcc.org.br/pesquisa/publicacoes/es/artigos/116. pdf $>$. Acesso em: 10 set. 2011.

SCHWARTZMAN, S. Aprendendo com os erros e os acertos do passado: pontos essenciais para a definição de políticas públicas de educação. Revista da Associação Brasileira de Mantenedoras de Ensino Superior, Brasília, DF, ano 27, n. 39, 2009.

. João Batista de Araújo e Oliveira: os três senhores do ENEM. Simon Education. 2010. Disponível em: $<$ http://www.schwartzman.org.br/ sitesimon/?p=1929\&lang=en-us $>$. Acesso em: 16 set. 2011. 
SISU. Como funciona. 2014. Disponível em: <http://sisu.mec.gov.br $>$. Acesso em: 16 jan. 2014.

UOL. ProUni tem $23 \%$ de faculdades participantes com nota baixa. Agência Estado. 2009. Disponível em: <http://educacao.uol.com.br/ultnot/2009/01/20/ ult4528u548.jhtm>. Acesso em: 18 jul. 2011.

. Em seis anos, uma em cada três bolsas do ProUni fica ociosa. UOL/Educação. 2011. Disponível em: <http:/educacao.uol.com.br/ noticias/2011/06/23/uma-em-cada-tres-bolsas-do-prouni-ficou-ociosa-entre2005-e-2011.htm>. Acesso em: 18 jul. 2011.

VALLE, I. R.; BARRICHELLO, F. A.; TOMASI, J. Seleção meritocrática versus desigualdades sociais: quem são os inscritos e os classificados nos vestibulares da UFSC (1988 - 2007)? . Linhas Críticas, Brasília, DF, v. 16, n. 31, jul./dez., p. 391-418, 2010.

VEJA. O mapa do Enem 2012. 2012. Disponível em: < http://veja.abril.com.br/ noticia/educacao/o-mapa-do-enem-2012>. Acesso em: 16 dez. 2012.

WEBER, D. Resultado do Enem 2010 mostra melhoria de desempenho de alunos. 2011. Disponível em: <extra.globo.com/noticias/educação/resultadodo-enem-de-2010-mostra-melhoria-de-desempenho-de-alunos-2611493.html $>$. Acesso em: 15 set. 2011.

WHITAKER, D. C. A. Universidade, Vestibulares e Ideologia. Perspectivas, São Paulo, n. 6, p. 123-131, 1983.

. Da "invenção" do vestibular aos cursinhos populares: um desafio para a Orientação Profissional. Revista Brasileira de Orientação Profissional, São Paulo, v. 11, n. 2, jul./dez., p. 289-297, 2010.

ZAGO, N. Do acesso a permanência no Ensino Superior: Processos de estudantes universitários de camadas populares. Revista Brasileira de Educação, Rio de Janeiro, v. 11, n. 32, p. 226-237, 2006. 


\section{Entrance examination and Enem: a contemporary debate \\ Abstract}

This article analyzes the most significant transformations that have occurred in the process of admission to undergraduate courses in Brazil. The theoretical foundation was based on discussing interests often hidden and present in the selection tools. As regards the methodological aspects, this is a descriptiveanalytical nature research. The results show that our selective processes of access to University, guided by an individualistic and competitive logic, set success almost exclusively as an individual responsibility, and it will dissemble an entire set of determinants factors for the approval of students.

Keywords: Educational Policies. Entrance examination. Enem.

\section{Selectividad y ENEM (Examen Nacional de Enseñanza Media en Brasil): un debate contemporáneo}

\section{Resumen}

Este artículo analiza las transformaciones más significativas que se han producido en el proceso de la selectividad en Brasil. La fundamentación teórica se basó en discutir sus intereses, que a menudo quedan ocultos, presentes en las herramientas de selección. En cuanto a los aspectos metodológicos, se trata de una investigación descriptiva y analítica. Los resultados muestran que los procesos selectivos de ingreso a la Universidad, guiados por una lógica individualista y competitiva, consideran el éxito casi exclusivamente como una responsabilidad individual y ocultan un conjunto de factores que son determinantes para la aprobación de los alumnos.

Palabras clave: Políticas educacionales. Selectividad. Enem. 